\title{
The Paradox of Democracy in Popular Music Education: Intersectionalizing "Youth" Through Curriculum Analysis
}

\author{
Minja Koskela, Anna Kuoppamäki, Sidsel Karlsen (D), and Heidi Westerlund
}

\begin{abstract}
In this chapter, we unpack the complex politics of popular music education (PME) in schools through an examination of the ways in which youth and youth culture are represented in the Finnish National Core Curricula (2004 and 2014). Interrogating commonly held conceptualizations of diversity in music education, we identify a paradox in school-based PME which, on the one hand, aims toward democratic classroom practice yet, on the other, neglects diversity by approaching youth as a homogenous group. Challenging common analytical points of departure in PME research, we argue that scholars and educators need to recognize the multiple and intersecting identities of students if PME is to afford them equal opportunities for participation. Overall, we suggest that through the analytical lens of intersectionality, PME may be better positioned to take into account students' own experiences of inequalities, providing new perspectives on diversity at the policy level. Thus, intersectionality could provide a useful analytical frame in the process of furthering further democratic practice in the classroom.
\end{abstract}

Keywords Popular music · Music education · Intersectionality · Democracy · Diversity · Curriculum

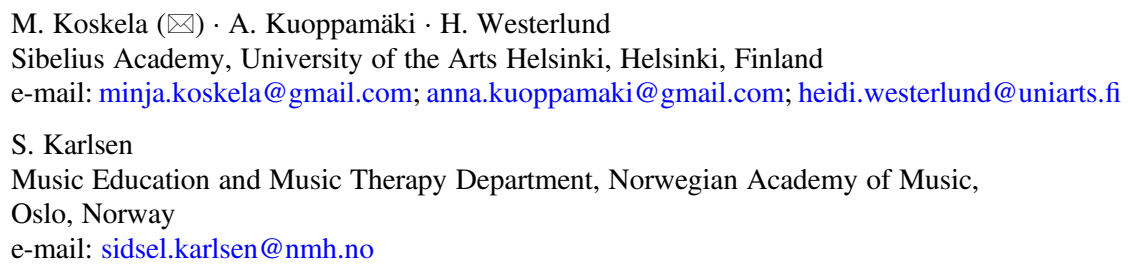




\section{Introduction}

In this chapter, we will address the need for change both in classroom practice as well as in policy texts, such as music curricula, in diversifying societies to better enhance democracy and tackle increasing inequalities. More specifically we will examine the ways in which students and students' culture are represented in the Finnish National Core Curricula (Finnish National Board of Education 2004, 2014), particularly in relation to the teaching and learning of popular music in increasingly culturally diverse Finnish schools. ${ }^{1}$ Heterogeneous societies - now defined as "super-diverse" (Vertovec 2007) ${ }^{2}$ - are facing a rise in xenophobic and nationalist expressions, requiring a new politics of diversity in order to enact solidarity. At the core of this global democracy project are young people, acting as the "architects for the future" (Mansouri 2017, p. 3).

For decades, popular music education (hereafter PME) has been treated as the democratizer of music education not just in Finland but globally. It has been argued that popular music making and garage bands "can serve as a model for nonhierarchical music education," thus increasing classroom democracy (Allsup 2011, p. 31), and that PME offers "the new channel of general musical learning" (Wright 2017, p. 10), pushing forward a broader democratic revolution in education. Underlying is the assumption that popular music best represents students' musical interests (e.g., Bennett 2000; Väkevä 2006) and that democratic practice in itself positions the student at the center of the learning process (e.g., Allsup 2011; Väkevä and Westerlund 2007; Väkevä 2006; Westerlund 2006). Consequently, popular music forms a well-established and somewhat hegemonic mode of musical expression within school music education in the Nordic countries (e.g., Dyndahl et al. 2017; Georgii-Hemming and Westvall 2010; Kallio and Väkevä 2017; Smith 2015). This is the case also in Finland, where popular music was first introduced in the school music curriculum in the 1960s (Väkevä 2006; Westerlund 2006).

The early inclusion of popular music in Finland, while lacking theorization of popular music's pedagogical implications was mainly based on the democratic ideals of PME enhancing students' participation by bringing youth culture as a point of departure of the teaching and learning (Väkevä 2006). This can be seen as a necessary shift from the dominant hegemony of classical music values. Earlier music education research indeed refers to popular music as teenagers" "own" music (e.g., Bennett 2000; Green 2006; Väkevä 2006). This premise is however not unproblematic. For example, according to Georgii-Hemming and Westvall (2010), the studies have shown that despite the general intention of education to

\footnotetext{
${ }^{1}$ For example, according to Statistics Finland's PX-Web Database (2019), the share of persons with foreign background in Helsinki has doubled between 2004 and 2016.

${ }^{2}$ According to Meissner and Vertovec (2016), super-diversity can be used in three different ways: (1) as a descriptive summary term to exemplify changes in population; (2) as a methodological term that seeks to understand complex new social formations; and (3) by highlighting the need to recognize new social conditions shaped by global migration and population change. Here we refer particularly to the second and third aspects.
} 
“take account of students' 'own' music" (p. 22), all students' musical worlds are not necessarily represented in the Swedish classroom. Furthermore, Kallio and Väkevä (2017) note that it is no longer possible to "rely on a consensus with regard to which popular music students identify with and call their "own" (p. 75). The rapidly diversifying teaching contexts undoubtedly beg us to question the premise of popular music as a "more or less homogenous cultural field shared and liked principally by the youth" (p. 78) and challenge the assumption of teenagers as a homogenous category which would unquestionably share similar musical interests. In this chapter, we ask: what kind of politics of diversity is represented in the national curriculum for basic education and music in Finland in terms of who the students are expected to be?

By analyzing the most important curricula texts guiding compulsory schooling in Finland, we wish to unpack the complexities of the politics of PME by showing that teachers in this context have to learn to engage in a complex negotiation between their own teacher education and the changing policy texts, which may be incompatible. As a whole, this chapter argues that the current analytical point of departure in PME research, which adopts youth as a taken-for-granted homogenous category, can be challenged by recognizing the multiple and intersecting identities of the students. Furthermore, we argue that such recognition would allow us to discuss democratic learning processes in a more complex analytical way through the notions of equal possibility for active participation and of radical democracy (Mouffe 2005), the latter emphasizing disagreements and diversity as prerequisites for democratic action. Radical democracy in music classrooms would require acknowledging diversity and letting it exist, thrive, and be addressed by allowing and encouraging a multiplicity of viewpoints and even disagreements. This approach would "indicate that democracy is alive and inhabited by pluralism" (Mouffe 2000, p. 34). Thus, in this chapter, we argue for such a negotiation of music education practices that can transform social and cultural structures and categories, thereby guiding young people to work not only as architects of their own lives but also as architects for the future.

\section{The National Core Curriculum and Popular Music in Finnish Schools}

Comprehensive schooling throughout grades 1-9 in Finland (students 7-15 years old) is publicly funded and governed. General education is guided by the National Core Curriculum, a policy document that aims to maintain the cohesion, quality, and legal protection of education throughout Finland. The most recent Core Curriculum for Basic Education (Finnish National Board of Education 2014) was published in 2014, and the process of implementing this curriculum started in 2016 and was completed in 2019. Following the structure of previous curricula, the document contains a general overview with guidelines for education relevant for all teachers 
and students and a subject-specific section, in which these broader guidelines are operationalized for each subject. Each school develops its own local curriculum based on the guidelines of the Core Curriculum - a process in which teachers are heavily involved and are afforded considerable autonomy.

The music curricula of the 1980s and 1990s and music teacher education in Finland emphasized the learning by doing principle (Muukkonen 2010). This emphasis is still visible in the 2014 music curriculum which highlights musical action as the basis of musical learning. In Finnish schools, the learning by doing principle is mainly executed through PME. The hegemony of popular music practices in Finnish general music education might be seen as a consequence of the music teacher education programs (Westerlund and Juntunen 2015), in which hands-on popular music skills have been emphasized and highly valued for decades as a response to the earlier hegemony of western classical music and emphasis on listening and singing. Popular music and popular band instruments fitted well with the idea of performance and music production being central in learning, even when struggling with the limited time and students' heterogeneous skills - an idea relevant in other than Finnish contexts, too. It is noteworthy that the popular music pedagogy in Finnish schools is not based on students' informal peer-learning processes, as in the seminal approach by Lucy Green (e.g., Green 2002, 2008); rather, it takes the teacher as an expert of student-centered popular music pedagogy (Westerlund 2006) and a facilitator in group teaching situations (e.g., Cremata 2017). However, it is notable that the 2014 music curriculum does not specifically emphasize popular music but rather musical versatility. Yet popular music often forms the starting point for classroom teaching and learning in Finnish schools (Kallio 2015).

\section{Theoretical and Analytical Lenses: Intersectionalizing Youth}

In this chapter, we understand social identities as multilayered and believe that each layer of one's identity might come with its related structural systems of oppression, domination, and discrimination. To acknowledge the relational interplay between the student identities and the structures involved in PME, we utilize intersectionality (e.g., Bradley 2016; Crenshaw 1989; Grzanka 2014) - a concept originally coined by Kimberlé Crenshaw (1989) in the context of fighting for black women's rights and recognition and currently imported into numerous disciplines that deal with inequalities and identities (Lutz 2015). Intersectionality is here used to highlight how social constructs and identities, such as social class, gender, race, age, sexuality, disability, and religious affiliation, intersect among youth and adolescents and, by doing so, also shape the social world and the structures of school in which inequality may be produced and experienced. By intersectionalizing youth, understood as a homogenous group of consumers of popular music, we aim to highlight how different social constructs and inequalities may co-construct one another in the 
classroom (see also Grzanka 2014, p. xiii). This contrasts with the past de-intersectionalization of "youth music," in which age has been taken as the main categorical criterion. De-intersectionalization is a process in which "the variety of possible relevant categories are ignored and people are treated by way of one, usually essentialized, category only" (Vertovec 2015, p. 13; also, Faist 2015). We thus recognize the use of the concept intersectionality as a political project meant to make the social and material consequences of various identification categories visible. Moreover, in line with Apple (1979) and Pinar et al. (1995), we understand the written curricular texts as political as they reproduce, as well as aim to transform, hidden structures and hegemonies of the society.

In the context of music education and PME, utilizing intersectionality enables shifting the focus from the musical styles and practices to the conditions in which musical action takes place and to the experiences of the students. Hence, we recognize that the very processes of community making and enacting solidarity (see above, Mansouri 2017) are not necessarily arising through musical repertoires but are conditioned by students' own identification and the categories that their peers and teachers use, or may not use, for identifying them. Furthermore, we acknowledge that one of the most important criteria for how music education is experienced by students with various backgrounds may be the possibility to cooperate musically in their everyday peer-group (see also Sæther 2008). Thus, intersectionality here serves as a lens for exploring the interplay between the different identities, school structures, and the conditions in which music education is put into action.

We use intersectionality as a methodology (e.g., Lutz 2015, p. 367) to identify representations of assumed categories related to students' identity in the Finnish National Core Curriculum as well as in the "inter-categorical" sense (p. 365) by problematizing the primacy of any specific category in PME, independent of the situation. Intersectionality is therefore used as "a heuristic device ... in detecting the overlapping and co-construction of visible and - at first sight - invisible strands of inequality" (p. 366). Previous music education research has pinpointed the workings of gender, sexuality, social class, ethnicity, and race (e.g., Bates 2019; Bradley 2007; Gould 2005; Green 2003; Hess 2015). However, given the vastly diversifying teaching contexts in Finland and worldwide, further understanding on the interrelatedness of student identities and structural inequity is needed. Building toward such understanding, intersectionality here serves as an analytic tool. Furthermore, for music educators to understand what popular music does within the school context requires an understanding of how "structures are constituted by the actions of agents (people, institutions)" and also that this "action itself is organized within the parameters of existing structures" (Bradley 2016, p. 14). It should be noted, however, that our analysis is limited to only providing scenarios of the potential mechanisms of inequality in PME. 


\subsection{The Method of Analysis}

To explore how the Finnish National Core Curriculum represents students, students' culture, and the aims of music education in the changing Finnish society and also how such articulations have changed over time, we have analyzed the curricula from 2004 (Finnish National Board of Education 2004) and 2014 (Finnish National Board of Education 2014). We analyzed the general part of both 2004 and 2014 curricula in order to identify the general changes in policy; however, the music subject part was analyzed only from the 2014 curriculum. ${ }^{3}$ We first coded curricular texts deductively by using qualitative content analysis (Brinkmann and Kvale 2014) and color coding to identify the categories that we attended to before exploring their intersections and consequences. The categories were selected by considering the demographic parameters which may construct "Otherness" and, thus, inequalities in their interplay with school's sociocultural structures. In defining the categories, we drew on the literature on intersectionality (e.g., Bradley 2016; Grzanka 2014; Lutz 2015) to unify our theoretical ground. These categories - also identified by Bradley (2016) - were social class, gender, "race," age, sexuality, disability, ethnicity, and religious affiliation. We then compared the two curricular texts with respect to which of these parameters was present and which was absent, in order to identify how students were represented in terms of identity categories and their intersections and also of how such representations might vary between the analyzed texts.

The analysis was conducted in three phases. Following our methodological choices, we followed the principles of inter-categorical complexity (McCall 2005), which "begins with the observation that there are relationships of inequality among already constituted social groups .... and takes those relationships as the center of analysis" (pp. 1784-1785). We then focused on the places in the curricular texts where understandings of culture, cultural diversity, or musical culture were articulated, either explicitly or implicitly through broader descriptions of society and of the surrounding world of the students. This was done to investigate how the policy texts envisioned the students' lifeworlds and the broader conditions for enacting the variety of cultural belongings on the societal level. Finally, the curricular representations of students and their surrounding cultural conditions were interpreted against the conception of "youth," and the understandings of popular music as equivalent with "students' own music," to grasp the complexity of the politics of diversity in school music in Finland.

\footnotetext{
${ }^{3}$ In a preliminary analysis communicated in a conference paper (see Koskela et al. 2017), the music subject part of the 2004 curriculum was also included. However, its content was not seen as vital for underpinning the findings discussed in this article.
} 


\section{Intersectionality and Cultural Diversity as Addressed in the Finnish Core Curricula}

The current Finnish National Core Curriculum for Basic Education (Finnish National Board of Education 2014) emphasizes equal opportunities for all students and calls for inclusive practices. Below, we will address the understanding of diversities through two broad themes, namely, how the analyzed two curricula texts represent the students in terms of identity categories and their possible intersections and how culture and cultural diversity are constructed. Finally, we will reflect these understandings with respect to PME in Finnish schools.

\subsection{Representing "The Student": Identity Categories and Their Intersections}

The general and overarching part of the Finnish 2014 curriculum considers a variety of social constructs on the part of the student, such as gender, culture, age, disability, ethnicity, sexuality, and religious affiliation, although the latter is only implicitly mentioned in relation to culture and cultural differences (see p. 30). Social class is not mentioned, the document refers to the varying socio-economic backgrounds of the students thus implying, yet not fully covering, the class difference. The multifaceted nature of gender is addressed, for example, by stating that one of the goals of schooling is to promote "information and understanding of the diversity of gender" (p. 18). In this respect, the 2014 curriculum clearly advances on the 2004 one, which mentions gender only twice throughout the whole document (see Finnish National Board of Education 2004, pp. 12 and 18).

Whereas the general part of the 2014 curriculum quite broadly recognizes a variety of identity categories, the music part of the curriculum employs a far narrower construction. This part of the text, extended to encompass three different grade spans (grades 1-2; grades 3-6; grades 7-9), centers on the music subject and its related practices and understandings, rather than employing a broad conception of who the student might be. Nevertheless, the music curriculum conveys an understanding of students as having their "own cultures" (p. 284), a "cultural heritage" (p. 152), and as belonging to "communities" (p. 284). Furthermore, age is mentioned once (p. 152), and the fact that students might have "different needs, abilities, and interests" (p. 152, see also p. 284 and p. 456) is noted, indicating an awareness of challenges related to social and ability differentiation. The student is only implicitly constructed as gendered, through recognizing that the teacher should aim to change "potentially gendered practices of the music culture and music instruction" (p. 456) and in using the expression of "his or her/him or her" to refer to the student. The latter strongly reinforces a binary gender system and limits other expressions of gender. Overall, however, the impression of the students as viewed through the 2014 music curriculum is that they, above all, are constructs of culture, in the sense that 
belonging to a culture, having a cultural heritage, and being connected to a community of some sort stand out as the primary markers of identification.

From the student's point of view, having an ethnic minority background and living in an area with low economic income might manifest as an experience of intersecting inequality. Thus, awareness of how identity categories and their corresponding (dis)advantages merge, transform, and overlap is needed if schools and teachers are expected to cater to the needs of a diverse group of students. Also, such lenses and knowledge are necessary for fulfilling the curricular aims of, for example, incorporating students' "musical interests" (p. 454), their "activities outside of school" (p. 454), and "expand[ing] their musical competence and worldview" (p. 454). In the music subject part, the complexity of students' social positioning is not addressed, and cultural diversity and interaction are mentioned solely in positive terms, as a source of richness and as something to respect (see p. 16). Another layer of complexity is removed from the curriculum, one which could have aided the teacher in navigating the diversifying society. We will next move from the level of how the student is represented and look further into how understandings of culture and of cultural diversity are shaped through the Finnish curricular texts.

\subsection{Representations of (Finnish) Culture and Cultural Diversity}

In the 2004 National Core Curriculum, Finnish culture is articulated as a homogenous monolith, from which non-Finnish cultures are differentiated and separated. The document states that "the basis of instruction is Finnish culture" (Finnish National Board of Education 2004, p. 12) and that students should be guided to understand the "essence of the Finnish and European cultural identities" (p. 37). Instruction should promote "tolerance and intercultural understanding" (p. 12), and Finnish culture is seen to be diversified "through the arrival of people from other cultures" (p. 12). Overall, though, a picture of Finnish culture as a solid and unified entity appears, both through the consistent use of the singular form ("culture"), the belief in "cultural essence," and the repeated distinctions between Finnish culture and "other cultures." This bipartition is also visible in the part of the curriculum that specifically handles Sámi students and the education in the Indigenous Sámi areas in Northern Finland. Instruction should 'reinforce the [Sámi] pupils' indigenous identity and afford possibilities for learning their own language" (p. 32), and they should have knowledge of "their own culture and history" (p. 32). There is no mention of the need for all students to familiarize themselves with Sámi cultures. In an understanding where Finnish culture is seen to have "an essence," Sámi students are positioned as being an "Other" to that essence and thus as outside of Finnish normality.

In contrast, the 2014 curriculum recognizes that Finnish culture has never existed as consistently coherent and that current societies are undergoing transformations. 
Finnish society is referred to as "culturally transforming and diverse" (Finnish National Board of Education 2014, p. 29) and also as a context "where the local and global overlap" (p. 29). Basic education should now be "built on a diverse Finnish heritage" (p. 16), and school should be a place for students to be "acquainted with cultural traditions, constructively discuss different ways of thinking and acting, and create new ways for acting together" (p. 29). The cultural diversity manifested in each and every student is underlined by pointing out that "[e)ach community and community member is multilingual" (p. 29) and that this multilingualism opens up different viewpoints and should be appreciated and encouraged. In the 2014 curriculum, the constructions of tradition, culture, and heritage no longer rely on the singular form but are plural to begin with, and any mentioning of essence with reference to culture is absent. The plurality is even acknowledged as existing within each student, which also means that no one in particular, or perhaps everyone within themselves, represents "the Other." The school system has been given the task, explicitly, to bring "up the importance of the Sámi culture and various minorities in Finland" (p. 29), so the responsibility for intercultural negotiation and exchange is no longer exclusively the task of the minorities themselves. Thus, the general part of the National Core Curriculum both seeks and in many ways succeeds to respond to the current societal changes in Finland.

The same openness toward inherent plurality cannot, however, be seen to characterize the 2014 music part of the curriculum. Here, again, the understanding of cultural heritage as singularly homogeneous is the dominant one (see Finnish National Board of Education 2014, p. 152, p. 284 and p. 455), and differences arise mainly from outside sources, through the students being allowed to "familiarize themselves with a diverse range of musical cultures and genres" (p. 152). Although not made explicit in the curricular text, the singular "cultural heritage" could be interpreted as being similar or close to the essentialized "Finnish culture" articulated in the 2004 curriculum, since there is no further discussion of what this heritage might be or to whom it might belong. Moreover, the view of musical differences that come into the classroom from outside could be construed as a reinstating of the bipartition between Finnish music/culture and other musics/cultures. Still, the music curriculum does acknowledge the plurality of students' cultures and communities (see p. 152) and conveys, as such, a limited recognition of complexity.

\subsection{Intersectionalizing "The Youth" in PME}

Whereas the general part of the 2014 curriculum manages to recognize multiple and varying identity categories, the music curriculum's construction of plurality is far narrower. Next, we will move on to explore how the understandings of student identities in music education practice and in related PME research relate to the constructions of plurality presented in the curriculum.

Through the comparison presented above, a picture emerges that shows how the understandings of diversity and diverse student identities have evolved over time in 
the Finnish National Core Curriculum and have gradually become more complex. However, the analysis also shows how teachers must navigate a complex array of constructions within one and the same document and thereby also apply diverse ideological starting points in their teaching practices, which in Finnish school music education strongly rely on PME. It is clear though that students' culture/cultures cannot be understood or essentialized as youth culture, or vice versa. To some extent this essentialization has, however, taken place in the earlier PME research when it has assumed popular music as teenagers' "own" music (e.g., Bennett 2000; Green 2006; Väkevä 2006), thus treating both "youth" and "popular music" as unified categories.

Nevertheless, nothing supports the assumption that students' own music should necessarily be equated with popular music. On the contrary, the latest research has shown that at its worst, PME policies can even work as instruments of social exclusion (Kallio and Väkevä 2017) and, thus, dissonances with regard to which (popular) music the teenagers call their "own." In short, whereas within the general part of the curriculum intersectional ideas have developed between 2004 and 2014, PME's premise of "youth" as a homogeneous category fails in acknowledging the plurality of teenagers. This premise is especially problematic now that the teaching contexts are diversifying rapidly thus including exponentially the varying musical worlds of the students. This is not to say that students' musical preferences would not serve as a sufficient starting point for pedagogical action, such as the earlier PME research suggests (e.g., Green 2006; Väkevä 2006; Wright 2017). Instead, the growing diversity calls for changing understanding of what these preferences are and for theorization of popular music's pedagogical implications (see also Väkevä 2006) with respect to changing pedagogical contexts. For this task, intersectionality might serve a useful tool, as intersectionalizing the category of "youth" reveals that treating teenagers as a homogeneous category may even lead to bypassing differences and inequalities. Moving toward a more complex understanding of diversity in PME and music education in general can also help the teachers to navigate their work within the changing teaching settings as well as to include students' varying musical worlds more competently in their teaching.

\section{Discussion: Toward a More Complex Politics of Diversity in (Popular) Music Education}

In this chapter we have argued that the current approach of PME, in which the "youth" category is used for justifying certain practices, obscures other categories that may be relevant to identity and related to experienced inequality in increasingly super-diverse societies. We have suggested that by using intersectionality as a lens to examine not just curricular texts but also the very educational practices that make use of them, we could enhance understandings of when, how, and why inequalities may potentially be experienced. Although the conceptualizations of the politics of 
diversity have seemingly deepened in Finnish compulsory school curricula in the period between 2004 and 2014, the ways that student identities and cultural diversity appear in the music subject curriculum do not represent the complexity of identity work nor the rapid changes of the population. While the general part of the 2014 Finnish National Core Curriculum does recognize different social constructs and acknowledges today's school and society as fluid and multiple, it at the same time fails in addressing how the various identity categories may intersect in the everyday lives of the students, even when the context can be described as seemingly homogeneous. Moreover, if popular music's use is justified by de-intersectionalizing (e.g., Vertovec 2015; Faist 2015) the category of youth, it may even further reinforce the assumption of homogeneity of students in the classroom.

Importantly, in the latest music curriculum, labels of musical styles and practices form the main way to address diversity, while in the general curriculum discourse, difference can also involve and point to inequality, injustice, and even discrimination. This change is not, however, manifested in the music curriculum in which difference is mainly taken as something to celebrate and sustain. The music curriculum, then, does not articulate teaching and learning situations as social constructs that are constructed with, through, and by different (and intersecting) social positions which may sustain cultural hegemonies. Furthermore, PME - even when understood as a heterogeneous and diverse category in itself (Allsup et al. 2012) - might not respond to Finnish National Core Curriculum's call for adding multiple musics to the educational repertoire, as a minimum attempt toward acknowledging diversity. Moreover, it is notable that even though religious affiliation appeared in our analysis only as implicated in culture and cultural differences, religion may have practical consequences in music teaching and learning situations. Religion, or belief, is indeed a category that seems vastly forgotten in PME scholarship (see however Kallio 2015 who identifies religion as one censorious narrative through which teachers in her study conducted their popular repertoire decisions), as well as by the Finnish music curriculum, and is rather taken as a matter of private space instead of an issue to be dealt with publicly. For instance, Westerlund et al. (2019) have argued that the development of secularism in schools has created a false assumption that students arrive at the music classroom without their (non)religious backgrounds or beliefs and identity categories.

This chapter has aimed to show that new perspectives on diversity discourses at the policy level are urgently needed and that intersectionality could provide a useful analytical tool in the process of rethinking how inequalities of PME in Finland, or elsewhere, could be tackled in classroom practices in schools. These perspectives are timely, as in a vastly diversifying society PME can no longer stem from an assumption of homogeneity of students and, thus, needs to acknowledge other social categories than youth, too. However, as Lappalainen and Lahelma (2016) state, we should perhaps not overstate the impact of national curricula but rather see these documents as a somewhat compromised reflection of the diverse powers operating in a society at a given time. Yet, the clear difference between the general guidelines in the latest Finnish National Core Curriculum and the music-specific part of the text raises further questions about how wider professional reflexivity and "praxis of 
intersectionality" (Bubar et al. 2016, p. 283) ought to be developed in music teacher education programs in the future. Acknowledging, cherishing, and debating diversity in the music classroom would also fulfill the radical democracy (Mouffe 2005) requirements of encouraging a multiplicity of viewpoints and even disagreements. This demands not only intersectionalizing youth in PME but also a deeper understanding of diversity in education in general. Reflexivity - a method which helps to analyze and challenge one's actions and immediate interpretations (e.g., Alvesson and Sköldberg 2018) - would then be a requirement for teachers and need to be practiced and developed also by students. This would enable teachers to extend their expertise as the facilitators of the student-centered curriculum and the students to better position themselves as architects of their own futures.

\section{References}

Allsup, R. E. (2011). Classical musicians and popular music: Strategies and perspectives. Music Educators Journal, 97(3), 30-34.

Allsup, R. E., Westerlund, H., \& Shieh, E. (2012). Youth culture and secondary education. In G. E. McPherson \& G. F. Welch (Eds.), The Oxford handbook of music education (Vol. 1, pp. 460-475). Oxford: Oxford University Press.

Alvesson, M., \& Sköldberg, K. (2018). Reflexive methodology: New vistas for qualitative research (3rd ed.). London: Sage Publications.

Apple, M. (1979). Ideology and curriculum. London: Routledge and Kegan Paul.

Bates, V. C. (2019). Standing at the intersection of race and class in music education. Action, Criticism, and Theory for Music Education, 18(1), 117-160.

Bennett, A. (2000). Popular music and youth culture: Music, identity and place. Basingstoke: Palgrave.

Bradley, D. (2007). The sounds of silence: Talking race in music education. Action, Criticism, and Theory for Music Education, 6(4), 132-162.

Bradley, H. (2016). Fractured identities: Changing patterns of inequalities (2nd ed.). Cambridge: Polity Press.

Brinkmann, S., \& Kvale, S. (2014). InterViews: Learning the craft of qualitative research interviewing (3rd ed.). Thousand Oaks: Sage Publications.

Bubar, R., Cespedes, K., \& Bundy-Fazioli, K. (2016). Intersectionality and social work: Omissions of race, class, and sexuality in graduate school education. Journal of Social Work Education, 52(3), 283-296. https://doi.org/10.1080/10437797.2016.1174636.

Cremata, R. (2017). Facilitation in popular music education. Journal of Popular Music Education, $1(1), 63-82$.

Crenshaw, K. (1989). Demarginalizing the intersection of race and sex: A black feminist critique of antidiscrimination doctrine, feminist theory and antiracist politics. University of Chicago Legal Forum, 1(8), 139-167.

Dyndahl, P., Karlsen, S., Nielsen, S. G., \& Skårberg, O. (2017). The academisation of popular music in higher music education: The case of Norway. Music Education Research, 19(4), 438-454.

Faist, T. (2015). Diversity unpacked. From heterogeneities to inequalities. In S. Vertovec (Ed.), Routledge international handbook of diversity studies (pp. 265-273). Abingdon and New York: Routledge.

Finnish National Board of Education. (2004). National core curriculum for basic education 2004. Finnish National Board of Education: Helsinki. 
Finnish National Board of Education. (2014). National core curriculum for basic education 2014. Finnish National Board of Education: Helsinki.

Georgii-Hemming, E., \& Westvall, M. (2010). Music education - A personal matter? Examining the current discourses of music education in Sweden. British Journal of Music Education, 27(1), $21-33$.

Gould, E. (2005). Desperately seeking Marsha: Music and lesbian imagination. Action, Criticism, and Theory for Music Education, 4(3), 2-18.

Green, L. (2002). How popular musicians learn: A way ahead for music education. Aldershot: Ashgate Press.

Green, L. (2003). Music education, cultural capital, and social group identity. In M. Clayton, T. Herbert, \& R. Middleton (Eds.), The cultural study of music: A critical introduction (pp. 263-274). New York: Routledge.

Green, L. (2006). Popular music education in and for itself, and for "other" music: Current research in the classroom. International Journal of Music Education, 24(2), 101-118.

Green, L. (2008). Music, informal learning and the school: A new classroom pedagogy. Aldershot: Ashgate.

Grzanka, P. R. (2014). Introduction: Intersectional objectivity. In P. R. Grzanka (Ed.), Intersectionality. A foundations and frontiers reader (pp. xi-xxvi). Boulder: Westview Press.

Hess, J. (2015). Upping the "anti-": The value of an anti-racist theoretical framework in music education. Action, Criticism, and Theory for Music Education, 14(1), 66-92.

Kallio, A. (2015). Navigating (Un)popular music in the classroom: Censure and censorship in an inclusive, democratic music education. (Doctoral dissertation). Sibelius Academy of the University of the Arts Helsinki. Helsinki: Studia Musica 65.

Kallio, A., \& Väkevä, L. (2017). Inclusive popular music education? In A. Kärjä \& F. Holt (Eds.), Oxford handbook of popular music in the Nordic countries (pp. 75-89). Oxford: Oxford University Press.

Koskela, M., Kuoppamäki, A., Karlsen, S., \& Westerlund, H. (2017, March). What counts as diversity? Intersectional investigations into Finnish national (music) curricula (Presented at Cultural Diversity in Music Education Conference XIII, Kathmandu, Nepal).

Lappalainen, S., \& Lahelma, E. (2016). Subtle discourses on equality in the Finnish curricula of upper secondary education: Reflections of the imagined society. Journal of Curriculum Studies, 48(5), 650-670. https://doi.org/10.1080/00220272.2015.1069399.

Lutz, H. (2015). Intersectionality: Assembling and disassembling the roads. In S. Vertovec (Ed.), Routledge international handbook of diversity studies (pp. 363-370). LondonlNew York: Routledge.

Mansouri, F. (2017). Interculturalism at the crossroads. Comparative perspectives on concepts, policies and practices. Paris: UNESCO Publishing.

McCall, L. (2005). The complexity of intersectionality. Signs: Journal of Women in Culture and Society, 30(3), 1771-1800.

Meissner, F., \& Vertovec, S. (2016). Comparing super-diversity. In F. Meissner \& S. Vertovec (Eds.), Comparing super-diversity (pp. 1-14). London: Routledge.

Mouffe, C. (2000). The democratic paradox. New York: Verso.

Mouffe, C. (2005). On the political. Abingdon: Routledge.

Muukkonen, M. (2010). Monipuolisuuden eetos. Musiikin aineenopettajat artikuloimassa työnsä käytäntöjä. [The Ethos of Versatility. Music Teachers Articulate Their Pedagogical Practices.] (Doctoral dissertation). Sibelius Academy of the University of the Arts Helsinki. Helsinki: Studia Musica 42.

Pinar, W. F., Reynolds, W. M., Slattery, P., \& Taubman, P. M. (1995). Understanding curriculum as political text. In W. F. Pinar, W. M. Reynolds, P. Slattery, \& P. M. Taubman (Eds.), Understanding curriculum: An introduction to the study of historical and contemporary curriculum discourses (Vol. 17, pp. 243-314). New York: Peter Lang Publishing.

Sæther, E. (2008). When minorities are the majority: Voices from a teacher/researcher project in a multicultural school in Sweden. Research Studies in Music Education, 30(1), 25-42. 
Smith, G. D. (2015). Seeking "success" in popular music. In C. Randles (Ed.), Music education: Navigating the future (pp. 183-201). New York: Routledge.

Statistics Finland's PX-Web Database: Numbers and shares of persons with immigrant background by area 1990-2017. (2019). http://pxnet2.stat.fi/PXWeb/pxweb/en/Maahanmuuttajat_ja_ kotoutuminen/Maahanmuuttajat_ja_kotoutuminen__Maahanmuuttajat_ja_kotoutuminen/005_ kaikki.px/?rxid=f424ad07-ab74-4320-a1c4-76e6c4957c57 Accessed 1 April 2019.

Väkevä, L. (2006). Teaching popular music in Finland: What's up, what's ahead? International Journal of Music Education, 24(2), 126-131.

Väkevä, L., \& Westerlund, H. (2007). The 'method' of democracy in music education. Action, Criticism, and Theory for Music Education, 6(4), 96-108.

Vertovec, S. (2007). Super-diversity and its implications. Ethnic and Racial Studies, 30(6), $1024-1054$.

Vertovec, S. (2015). Introduction: Formulating diversity studies. In S. Vertovec (Ed.), Routledge international handbook of diversity studies (pp. 1-20). Abingdon and New York: Routledge.

Vision Europe Summit. Improving the Responses to the Migration and Refugee Crisis in Europe. (2016). https://static1.squarespace.com/static/54c95cbee4b03749141be705/t/ $582 \mathrm{~b} 24805016 \mathrm{e} 1 \mathrm{e} 43 \mathrm{~d} 9 \mathrm{~d} 16 \mathrm{~b} 1 / 1479222407182 /$ Improving+the+Responses+to+the+Migration + and+Refugee+Crisis+in+Europe+\%28web\%29.pdf. Accessed 28 June 2020.

Westerlund, H. (2006). Garage rock bands: A future model for developing musical expertise? International Journal of Music Education, 24(2), 119-125.

Westerlund, H., \& Juntunen, M.-L. (2015). Music education and teacher preparation in Finland: Facing plurality of musics and needs. In S. Figueiredo, J. Soares, \& R. F. Schambeck (Eds.), The preparation of music teachers: A global perspective (Vol. 5, pp. 195-218). Série Pesquisa em Música no Brasil: ANPPOM - The National Association of Research and Post Graduate Studies in Music: Porto Alegre.

Westerlund, H., Kallio, A. A., \& Partti, H. (2019). The performativity of performance: Agency at the intersection of music and religion in school. In A. A. Kallio, P. Alperson, \& H. Westerlund (Eds.), Music, education, and religion: Intersections and entanglements. Bloomington: Indiana University Press.

Wright, R. (2017). The longer revolution: The rise of vernacular musics as 'new channels of general learning'. Journal of Popular Music Education, 1(1), 9-24.

Minja Koskela is a doctoral candidate in music education at the Sibelius Academy of the University of the Arts Helsinki. Koskela has taught music in high school and upper elementary school level for 5 years. In her doctoral dissertation, she explores the democracy of popular music education through intersectional feminism and inquires into her own teaching context. She has written popular nonfiction books on her research area (Ennen kaikkea feministi [A feminist before all else] 2019; Toisin tehty - keskusteluja koulusta [Differently Done - Conversations about school] 2020).

Anna Kuoppamäki (DMus) is a music educator, songwriter, and music education researcher. Kuoppamäki works as a teacher at the Music School of West Helsinki and as a postdoctoral researcher in ArtsEqual research initiative coordinated by the University of the Arts Helsinki. She is also an experienced workshop leader and teacher-in-service trainer and has given courses on creative and interactive teaching methods widely across Finland. In her current project, G Songlab that offers open-access and free-of-charge songwriting workshops for young people interested in writing their own music, she examines the meanings of songwriting, particularly as part of citizenship agency.

Sidsel Karlsen is Professor of Music Education at the Norwegian Academy of Music where she also serves as one of the leaders of the Centre for Educational Research in Music (CERM). Karlsen is also a docent at the Sibelius Academy, University of the Arts Helsinki in Finland, and one of two 
PIs in the research project Global visions through mobilizing networks: Co-developing intercultural music teacher education in Finland, Israel, and Nepal. Karlsen has published widely in international research journals, anthologies, and handbooks and serves on several international editorial boards.

Heidi Westerlund has been working as professor at the Sibelius Academy, University of the Arts Helsinki, Finland since 2004. She has served in the editorial and reviewer boards in several international journals and is the editor in chief of the Finnish Journal of Music Education. She is the co-editor of Collaborative learning in higher music education (Ashgate, 2013), Perspectives on Music, Education and Religion: A Critical Inquiry (Indiana University Press, 2019), and Visions for Intercultural Music Teacher Education (Springer, 2020). She is the PI in The arts as public service: Strategic Steps toward Equality (2015-2021) and Global Visions Through Mobilizing Networks: Co-developing Intercultural Music Teacher Education in Finland, Israel and Nepal (2015-2020), as well as the CO-PI in Music for Social Impact: Practitioners' Contexts, Work, and Beliefs, AHRC (2020-2022).

Open Access This chapter is licensed under the terms of the Creative Commons Attribution 4.0 International License (http://creativecommons.org/licenses/by/4.0/), which permits use, sharing, adaptation, distribution and reproduction in any medium or format, as long as you give appropriate credit to the original author(s) and the source, provide a link to the Creative Commons license and indicate if changes were made.

The images or other third party material in this chapter are included in the chapter's Creative Commons license, unless indicated otherwise in a credit line to the material. If material is not included in the chapter's Creative Commons license and your intended use is not permitted by statutory regulation or exceeds the permitted use, you will need to obtain permission directly from the copyright holder.

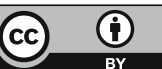

